УДК $351 / 321: 323$

DOI 10.15673/fie.v13i4.2192

Добрянська Н.А.

доктор економічних наук, профресор кафедра туристичного бізнесу і рекреації

E-mail: semen-198@te.net.ua

ORCID ID: 0000-0002-0826-8840

Ніколюк О.В.

доктор економічних наук, профресор кафедра публічного управління

та адміністрування

Email: alenavn11@gmail.com

ORCID ID: 0000-0002-1665-0361
Саркісян Г.О.

доктор економічних наук, профресор кафедра туристичного бізнесу і рекреації

E-mail: anutasark@gmail.com

ORCID ID: 0000-0001-7362-3637

Єланська К.В.

магістрант

кафредра туристичного бізнесу і рекреації

Одеська національна академія харчових технологій

вул. Канатна 112, м. Одеса, Україна, 65039

E-mail: elanskayakatya@gmail.com

ORCID ID: 0000-0002-8584-4709

\title{
АНАЛІЗ МІЖНАРОДНОГО РИНКУ ГОТЕЛЬНИХ ПОСЛУГ: ПРОБЛЕМИ I ТЕНДЕНЦІї РОЗВИТКУ
}

Індустрія гостинності $€$ однією 3 найактивніших у світі, тому завжди змінюється та перебуває у пошуках нового. У статті досліджено стан сучасного ринку готельних послуг, проаналізовано сучасні світові тенденції індустрії гостинності. Окреслено питому вагу ночівлі туристів в закладах розміщення Європейського регіону, для детального аналізу були використані показники Євростату. Так більшість припадає на готелі та схожі заклади розміщення, а найменша кількість на кемпінги та трейлери. Проведено аналіз динаміки показників кількості ночівель, які провели туристи в закладах розміщення в Європейському регіоні, в результаті, в період з 2010 по 2019 роки, спостерігається позитивна динаміка. Визначено, що під впливом пандемії COVID-19, змінились побажання, щодо споживання готельних послуг, більшість клієнтів закладів розміщення бажають бачити збільшення кількості прибирань та дезінфекції приміщення, дотримання соціальної дистанції та тимчасове припинення деяких видів готельного сервіс: СПА, казино, ресторан. Розглянуто, що сьогодні велика кількість мандрівників під час бронювання віддає перевагу мобільним додаткам готелю, а левова частка бронювань здійснюється через мобільні пристрої. Прогнозується, що скоро третина замовлень турів буде здійснюватися також через мобільні пристрої. Обрані шляхи для покрашення функціонування ринку готельних послуг

Ключові слова: туризм, ринок готельних послуг, індустрія гостинності, готель, бронювання, мобільний додаток.

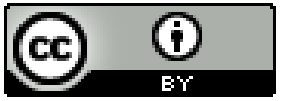

This work is licensed under a Creative Commons Attribution 4.0 International License http://creativecommons.org/licenses/by/4.0/
Постановка проблеми та ії зв'язок з важливими науковими та практичними завданнями. Міжнародний ринок готельних послуг постійно змінюється під впливом різних чинників: глобалізація, посилення автоматизації технологічних процесів, створення інноваційних технологій, пандемія COVID19. Тому проблематика ринку готельних послуг та його модернізація будуть завжди актуальні. Цей ринок потребує постійного моніторингу даних для розробки рішень щодо покращення процесу надання послуг у сфері гостинності. При розробці рішень щодо покращення сервісу необхідно приділяти увагу сучасним світовим тенденціям аби бути готовим у будьякий час задовольнити бажання клієнтів.

Аналіз останніх публікацій по проблемі. Дослідженням питання розвитку міжнародного ринку готельних послуг, аналізом статистичних даних, еволюцією готельної індустрії займаються багато вчених, серед них Мєнькова С. С. [1], Щетиніна К.І. [2]
Михайличенко К. І. [1], Шевченко С. І. [1]. Внесок у дослідження ринку готельних послуг здійснили Гарбера O.С. [3], Посохов С.I. [4]. Зарубіжні науковці також також зробили внесок в аналіз функціонування ринку, ними є Дж. Уокер, Ед. Коен, К. ЕнертонТомас, Taxipi А [17], Лекікі Б. [17].

Формулювання цілей дослідження. Метою статті $є$ дослідження сучасного стану ринку готельних послуг, аналіз тенденції ринку та розроблені рекомендації щодо покращення надання готельних послуг.

Виклад основних результатів та їх обгрунтування. Немає чіткого поняття, що таке ринок, але як зазначає Дж. Хоук, ринок - це сукупність фактичних або потенційних покупців і продавців певного товару або послуг. Взаємодія цих покупців та продавців породжує набір взаємопов'язаних цін та умов продажу або послуг. Принципи чи факти, що визначають які покупці та продавці перебувають на тому 
чи іншому виді ринку, визначають ринок просторово, часово та політично [15]. Тобто ринок готельних послуг - це сукупність фактичних або потенційних споживачів і готельних підприємств-виробників певного товару або послуг. Учасниками міжнародного ринку готельних послуг є споживачі та виробники індустрії гостинності.

Ринок змінюється на основі різних чинників, а тим паче, під впливом пандемії (COVID-19), тому він потребує постійного моніторингу для розробки рішень щодо покращення якості сервісу в наданні готельних послуг та інтенсивного дослідження. Індустрія гостинності стрімко розвивається завдяки збільшенню попиту на послуги сфери відпочинку, а також збільшенню можливостей для подорожей. В результаті, заклади розміщення стикаються 3 вибагливою клієнтурою, оскільки вимоги до якості зростають iз збільшенням використання готельних послуг, для підвищення конкурентоспроможності готелю важливим $є$ питання лояльності клієнтів.

Учасниками ринку є виробники готельних послуг - готельні підприємства, які мать право на готельну діяльність згідно законодавству; особи, які провадять діяльність 3 надання посередницьких послуг; споживачі, потенційні клієнти послуг.

За даними «Condor Ferries» індустрія гостинності має тенденцію до зростання тому, що на сього- днішній день вона налічує понад 700 тис. закладів розміщення по всьому світу та внесок у світову економіку понад 3,41 млрд. доларів США. У 2019 році світова готельна індустрія становила 570 млрд. доларів США.

Зростання купівельної спроможності, бажання подорожувати та зростаюча кількість цифрових впливів сприяють зростанню туристичної індустрії. Мандрівники витрачають понад 840 мдрд. доларів на рік на проживання в готелях по всьому світу [5].

Сучасна індустрія гостинності відрізняється від інших суміжних видів діяльності у сфері надання житла безперервним підтриманням якості послуг та обов'язковим впровадженням нових видів послуг, не характерних для готельного бізнесу, а все для підвищення якості базових послуг: розміщення та задоволення потреби сучасних споживачів. Від підвищення якості готельних продуктів і послуг залежить виживання готельного господарства на вимогливому та динамічному ринку та підвищення рівня конкурентоспроможності. Готельні компанії, орієнтовані на якість, а отже, і на задоволення своїх гостей, можуть бути успішними на вимогливому туристичному ринку, адже на прикладі Свропейського регіону, за даними Євростату у 2020 році (рис.1), ми можемо бачити, що для ночівлі туристи обирають саме заклади розміщення готельного типу [6].

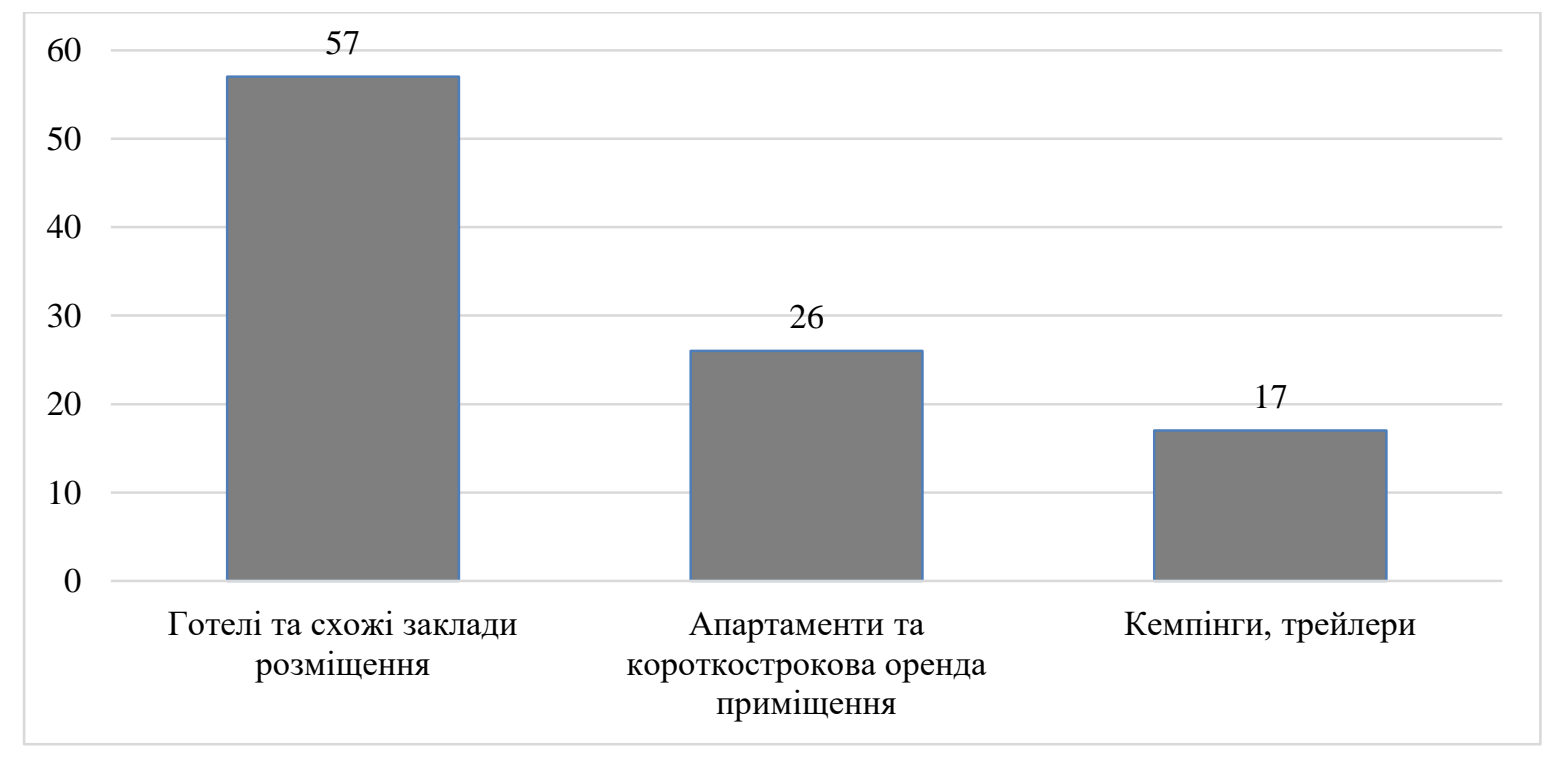

\section{Рис. 1. Питома вага ночівель туристів в закладах розміщення за типами в Свропейському регіоні в 2020 році, \% \\ * побудовано автором на основі інформації Свростата [6]}

У 2020 році спостерігалось, що більше половини туристів віддають перевагу закладам розміщення готельного типу, чверть обирає апартаменти або приміщення, які можна орендувати на короткий строк, а 17\% віддає перевагу кемпінгам та трейлерам.

Індустрія гостинності в ринкових умовах 3 метою досягнення комерційного ефекту пропонує розміщення та інші готельні послуги, які вона використовує для задоволення потреб і мотивів гостей та відвідувачів, а також для забезпечення рівня життя свого персоналу та керівництва. Під час тимчасового перебування в готелях, у напрямку обраної туристичної дестинації, готельна індустрія пропонує туристам відпочинок та розслаблення, дає можливість діловим людям налагодити ділові контакти; створює чудові умови для учасників конференцій, семінарів та різноманітних інших професійних, наукових та політичних зустрічей; дає можливість відвідувачам ознайомитись iз природними, культурними та історичними пам'ятками; послуги харчування для місцевих жителів, 
а також різноманітні розважальні заклади [7-8; 13-14]. Численні тенденції підкреслюють важливість сучасного готельного бізнесу, оскільки сучасний турист не задовольняється лише первинною пропозицією готельних закладів, а вимагає диференційованого та персоналізованого обслуговування, що стає основним мотивом подорожі. А саме, мотиви вже не стосуються виключно відпочинку та інертного проведення вільного часу.
Кожен рік країни-члени СС подають до Евростату статистичну інформацію про кількість прибуттів та ночівель резидентів та нерезидентів у закладах розміщення в цілому по країні та в регіональному poзpisi.

Аналізуючи дані Евростату, ми можемо бачити тенденцію (рис.2) до збільшення кількості ночівель, які провели туристи в закладах розміщення на прикладі Європейського регіону [9].

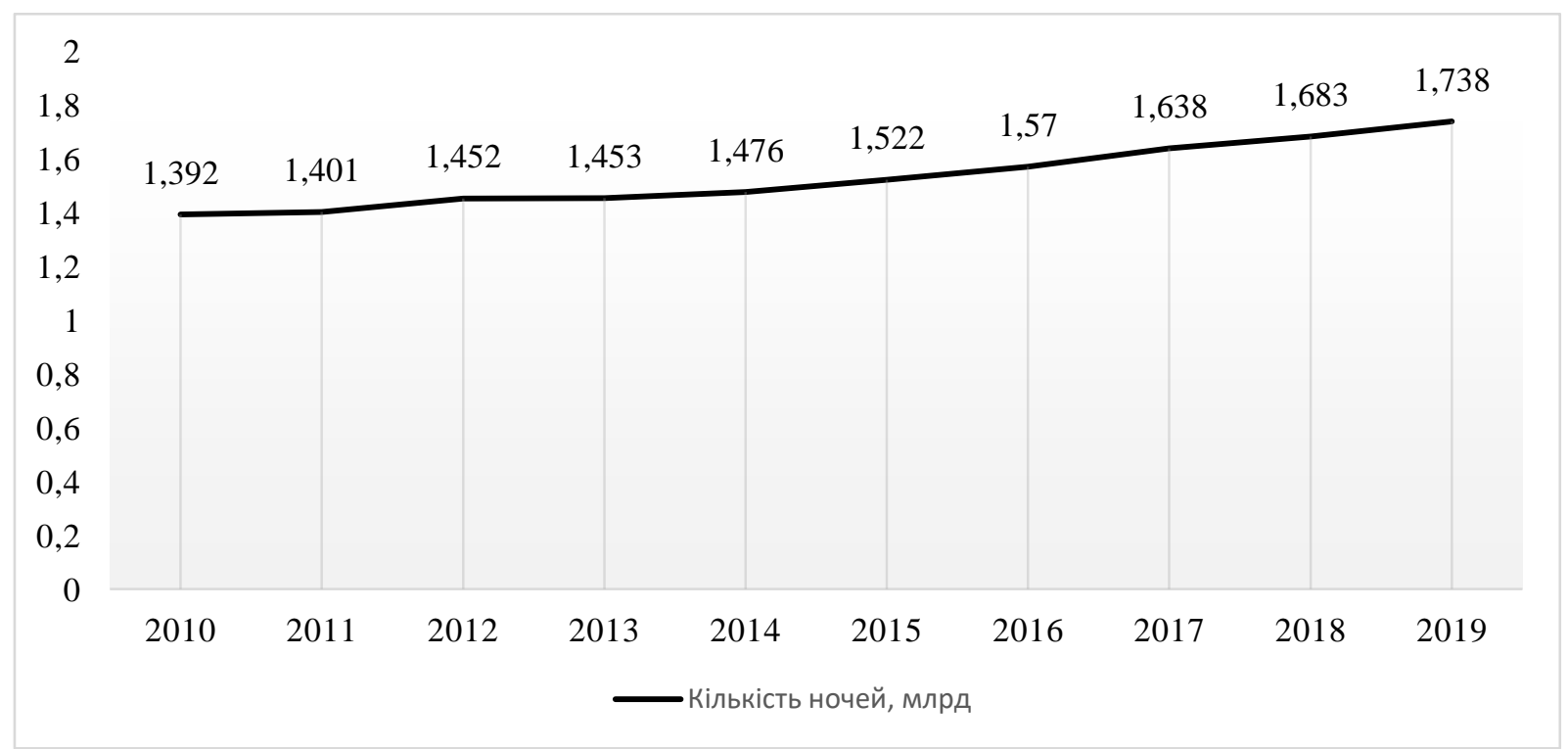

Рис. 2. Динаміка кількості ночівель, які провели туристи в закладах розміщення в Свропейському регіоні, млрд. ночей

*побудовано автором на основі інформації Євростата [9]

Тобто за останні дев'ять років ми можемо підрахувати, що кількість ночівель збільшилась на 24\%, що може свідчити про те, що розміщення в закладах гостинності досі актуальне та затребуване у туристів. Якби у світі не сталася пандемія коронавірусу (COVID-19), то можна припустити, що кількість ночівель $з$ кожним роком зростала б.

Звичайно, в результаті епідемії коронавірусу (COVID-19) ставлення туристів у світі змінилося, особливо з позиції сприйняття показника комфорту при перебуванні у закладах розміщення. Згідно з опитуванням Statista, станом на травень 2020 року (рис.3) $13 \%$ опитуваних висловились, що бажають аби назавжди припинили свою діяльність такі види готельного сервісу як казино, спа та ресторан. Проте, 60\% опитуваних заявили, що їм було б комфортніше залишатися в готелях після пандемії коронавірусу, якби частіше проводилися процедури очищення та дезінфекції [10].

На нашу думку, можемо сподіватись на продовження зростання попиту на ночівлю в закладах розміщення проте не так стрімко, як було до пандемії коронавірусу (COVID-19).

Конкуренція на готельному ринку послуг це суперництво між готельними підприємствами за найбільш вигідні умови виробництва і реалізації 3 метою досягнення матеріальної вигоди. Характер конкуренції на ринку готельних послуг, як і на будь- якому іншому ринку, залежить від конкурентних сил. Сила цих сил визначає потенціал прибутку, де потенціал прибутку вимірюється 3 точки зору довгострокової рентабельності вкладених коштів.

Сьогодні налічується велика кількість готельних підприємств. Сьогодні найбільшими готельними мережами світу $€$ «Marriott International» - 7500 закладів проживання; «Jin Jiang» - 10000 закладів; «Hilton Hotels» - 6000 закладів; «InterContinental Hotel Group (IHG)» - 6000 закладів; Wyndham Hotel Group 8941 заклад [16].

Тому, щоб вижити в сучасних умовах конкуренції готельні мережі закладів розміщення повинні стежити за тенденціями та впроваджувати інновації.

За останні роки, з'явилася велика кількість сучасних, обізнаних мандрівників, і вони очікують, що готелі будуть також вдосконалюватись. Навіть старше покоління тепер добре розбирається у використанні соціальних медіа та мобільних пристроїв двох речей, які є необхідними у сучасному житті готельної індустрії. Це означає веб-сайти, зручні для мобільних пристроїв, зручну та просту навігацію та зрозумілий i швидкий процес бронювання. Навіть набираючи натхнення для подорожей, люди використовують мобільні технології для перегляду Facebook або Instagram, тому готелі потребують постійної присутності в медіапросторі. 


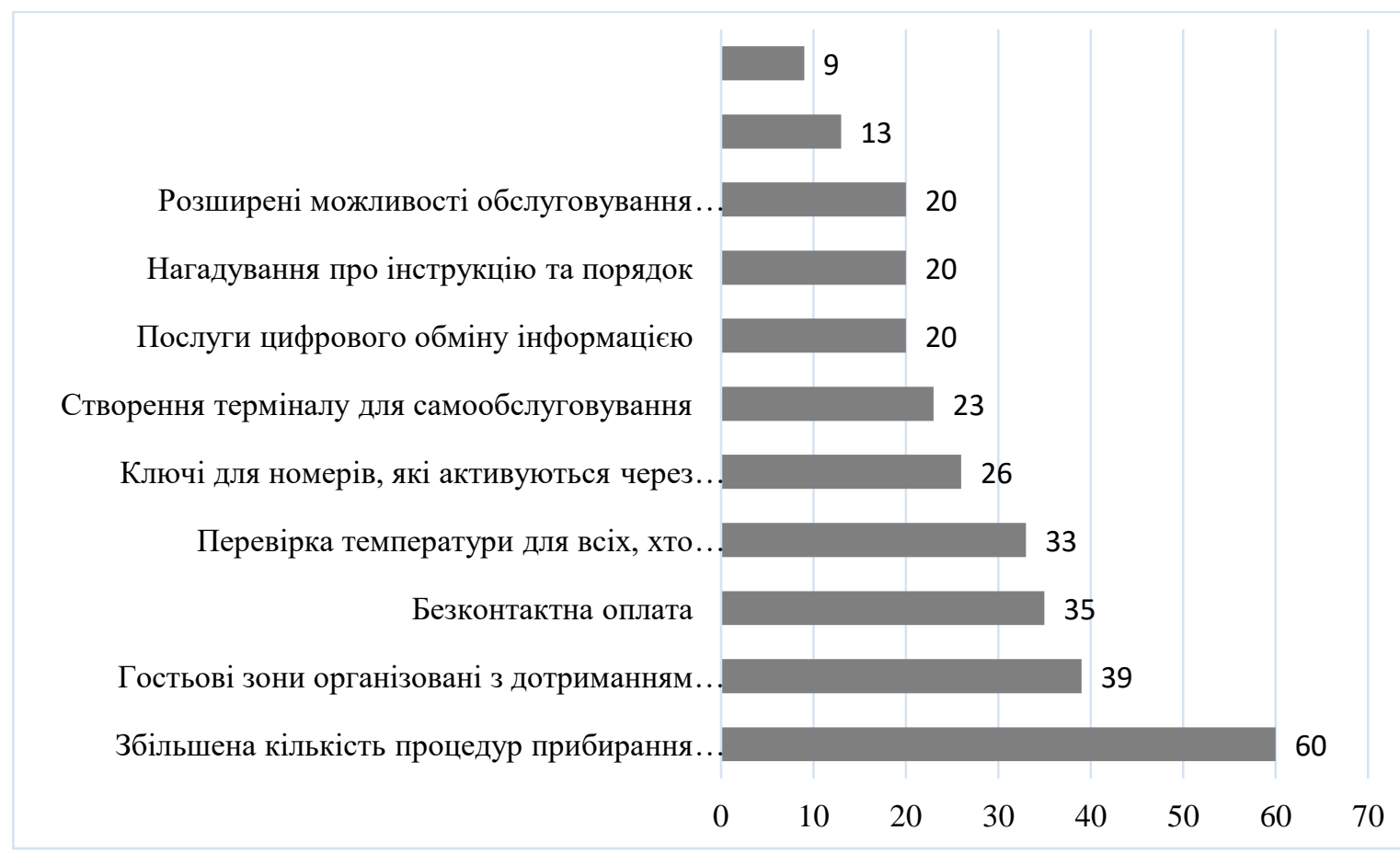

Рис. 3. Опитування респондентів щодо підвищення рівня комфорту кліснтів у готелях в період пандемії коронавірусу (COVID-19) у всьому світі станом на травень 2020 року * дані сайту Statista [10]

Мобільний зв'язок стає все більш важливим. Клієнти знаходять більше способів вирішення власних запитів. Одним із методів, які вони використовують, є завантаження мобільних додатків. В процесі бронювання готелю, вони сподіваються, що зможуть легко перевірити свої дані та миттєво взаємодіяти 3 обраним готелем через додаток, а не електронною поштою, телефоном чи веб-сайтом. Так за даними інтернет-ресурсу «Criton», у 2019 році 70\% бронювань готелів в останню хвилину здійснювались на мобільних пристроях, а готельний додаток та інші готельні технології впливали на рішення при бронюванні на 70\% мандрівників [11]. Інтернет-ресурс «Рhocuswright» стверджує, що до 2022 року понад третина замовлень європейських онлайн-турагентств буде здійснюватися через мобільні веб-сайти та додатки [12].

Висновки та перспективи подальших досліджень. Індустрія подорожей та гостинності більше не керується традиційними методами. Власники туристичного та готельного бізнесу вже давно автоматизують свої процеси, щоб підвищити продуктивність і задоволеність клієнтів. Результатом стало значне підвищення ефективності надання послуг у всьому світі та більш стандартизований спосіб роботи 3 клієнтами. Технологія вплинула на ці сектори найбільш позитивним чином.

Тому сьогодні, для успішного функціонування ринку готельних послуг, необхідно впровадження сучасних технологій, таких як створення додатку для готелю; модернізація готелю зсередини: встановлення розумних замків, які можна буде відчиняти за допомогою смартфонів; встановлення голосового помічника зі штучним інтелектом в номерах; залучення віртуальної реальності для більш зручного бронювання номерів; впровадження безконтактної реєстрації.

\section{Література}

1. Менькова Е. С., Шевченко Е. И., Михайличенко К. И. Анализ мирового рынка гостиничной отрасли // Современные научные исследования и разработки. 2019. №. 1. С. 689 - 701.

2. Щетинина К. И. Тенденции развития европейского рынка гостиничных услуг: дис. ... канд. экон. наук: 08.00.14: защита 06.09.2016 г. / Науч. рук. д.э.н., доцент Дементьева А.Г. Москва: МГИМО 2016.192 с.

3. Гарбера О.С. Світове господарство і міжнародні економічні відносини // Економічний часопис XXI. 2010. 11 груд. С. $37-41$.

4. Посохов І.С. Сучасні тенденції розвитку готельно-ресторанного бізнесу: міжнародний та національний досвід: колективна монографія / за заг. ред. А.Ю. Парфіненка. Харків: ХНУ імені В.Н. Каразіна, 2017.412 c. http://ekhnuir.univer.kharkov.ua/handle/123456789/13345 (дата звернення: 02.10.2021).

5. Explore Hotel Industry Statistics \& Trends including Average Occupancy, Rates, Global Hotel Industry Trends \& More: [website]. URL: https://www.condorferries.co.uk/hotel-industry-statistics (viewed on: 02.10.2021). Seasonality in the tourist accommodation sector: [website]. URL: https://ec.europa.eu/eurostat/statistics- 
explained/index.php?title=Seasonality_in_the_tourist_accommodation_sector\#By_accommodation_type (viewed on: 02.10.2021).

6. Seasonality in the tourist accommodation sector: [website]. URL: https://ec.europa.eu/eurostat/statisticsexplained/index.php?title=Seasonality_in_the_tourist_accommodation_sector\#By_accommodation_type (viewed on: 02.10.2021).

7. Cerović, Z. Hotelski menadžment. Opatija: Fakultet za hotelski i turistčki menadžment, 2010. $850 \mathrm{~s}$. 2008. $84 \mathrm{~s}$

8. Bunja, Đ. Organizacija poslovanja u hotelijerstvu i turizmu: hotel i hotelijerstvo. Zagreb: Školska knjiga,

9. Nights spent at tourist accommodation establishments: [website]. URL: https://ec.europa.eu/eurostat/web/products-datasets/-/tour_occ_ninatT (viewed on: 02.10.2021).

10. Public opinion on how to improve customer comfort levels in hotels after the coronavirus (COVID-19) pandemic worldwide as of May 2020: [website]. URL: https://www.statista.com/statistics/1155082/coronavirus-hotelslevel-of-comfort-improvement/ (viewed on: 02.10.2021).

11. Top 30 mobile marketing stats for hotels: [website]. URL: https:/www.criton.com/news-hub/30-mobilemarketing-stats-for-hotels-in-2019/ (viewed on: 02.10.2021).

12. Despite challenges, OTA bookings continue to climb in Europe: [website]. URL: https://www.phocuswright.com/Travel-Research/Research-Updates/2019/Despite-challenges-OTA-bookings-continueto-climb-in-Europe (viewed on: 02.10.2021).

13. Dobrianska N., Nikoliuk O., Lebedieva V. Organizational and economic measures of tourism development on the example of the Avangard United Territorial Community of Odessa region// Food Industry Economics. 2019. Vol.11, Issue 3. P. 88-96. doi: 10.15673/fie.v11i3.1466

14. Добрянська Н.А., Попович В.В. «Зелений» туризм як стратегічний напрям соціально-економічного розвитку регіонів України. // Економіка: реалії часу. 2018. № 3 (37). C. 20-28. URL: https://economics.opu.ua/files/archive/2018/No3/20.pdf. DOI: 10.5281/zenodo.1326369. (дата звернення: 02.10.2021) $353-356$

15. Houck J.P. «Market»: A Definition for Teaching // Western Journal of Agricultural Economics. 1984. C.

16. Top 10 largest hotel groups of the world: [website]. URL:https://www.tourism-review.com/top-10-worldlargest-hotel-groups-news1988 (viewed on: 02.10.2021).

17. Tahiri A., Kovaçi I., Lekiqi B. Tourism and Hotel Industry: Definition, Concepts and Development - The Case of Kosovo // Quality - Access to Success. 2021. 22(182). P. 110-115.

Стаття надійшла 17.10.2021

Стаття прийнята до друку 31.10.2021

Доступно в мережі Internet 30.12.21

Dobrianska N.

Doctor of Economics, Professor

Department of Tourism Business and Recreation

E-mail: semen-198@te.net.ua

ORCID ID: 0000-0002-0826-8840

Nikoliuk 0.

Doctor of Economics, Professor

Department of Public Administration

Email: alenavn11@gmail.com

ORCID ID: 0000-0002-1665-0361
Sarkisian G.

Doctor of Economics, Professor

Department of Tourism Business and Recreation

E-mail: anutasark@gmail.com

ORCID ID: 0000-0001-7362-3637

\section{Yelanska K.}

Undergraduate

Department of Tourism Business and Recreation

Odessa National Academy of Food Technologies

Kanatna str., 112 Odesa, Ukraine, 65039

E-mail: elanskayakatya@gmail.com

ORCID ID: 0000-0002-8584-4709

\section{ANALYSIS OF THE INTERNATIONAL MARKET OF HOTEL SERVICES: PROBLEMS AND DEVELOPMENT TRENDS}

The article examines the state of the modern hotel services market, analyzes the current global trends in the hospitality industry. The international hotel services market is constantly changing under the influence of various factors: globalization, strengthening of the automation of technological processes, the creation of innovative technologies, the COVID-19 pandemic. Therefore, the issues of the hotel services market and their modernization will always be relevant. This market needs constant monitoring of data to develop solutions to improve the process of providing hospitality services. The share of accommodation stays of tourists in the places of residence of the European region has been indicated, Eurostat indicators were used for the detailed analysis. So most accommodations are in hotels and similar establishments, and 
the least number are in camping's and trailers. The modern tendencies of the market, its problems have been reflected. The analysis of the dynamics of the number of nights spent by tourists in restaurants in the European region, has been carried out as a result, in the period from 2010 to 2019, there is a positive trend. It has been determined that under the influence of the COVID-19 pandemic, wishes regarding the consumption of hotel services have changed, most customers want to see an increase in cleaning and disinfection of premises, social distance and temporary cessation of some hotel services: spa, casino, restaurant. It has been analyzed that today a large number of travelers prefer the hotel's mobile applications when booking, and the lion's share of bookings are made via mobile devices. It is projected that soon a third of tour orders will also be made via mobile devices. The ways have been chosen to improve the functioning of the hotel services market.

Key words: tourism, hotel services market, hospitality industry, hotel, booking, mobile application.

\section{References}

1. Menkova, E. S., Shevchenko, E. I., \& Mihaylichenko, K. I. (2019). Analiz mirovogo ryinka gostinichnoy otrasli. Sovremennyie Nauchnyie Issledovaniya i Razrabotki, (1), 689-701.

2. Schetinina, K. I. (2016). Tendentsii razvitiya evropeyskogo ryinka gostinichnyih uslug (dissertation: ... kand. ekon. nauk: 08.00.14: zaschita 06.09.2016g., Nauch.ruk. d.e.n., dotsent Dementeva A.G. ). MGIMO, Moskva.

3. Harbera, O. Ye. (2010). Svitove hospodarstvo i mizhnarodni ekonomichni vidnosyny. Ekonomichnyi chasopys - XXI, $37-41$.

4. Posokhov, I. S. (2017). Suchasni tendentsii rozvytku hotelno-restorannoho biznesu: mizhnarodnyi ta natsionalnyi dosvid. (A. Yu. Parfinenko, Ed.). KhNU imeni V.N. Karazina. Retrieved October 2, 2021, from http://ekhnuir.univer.kharkov.ua/handle/123456789/13345.

5. Explore Hotel Industry Statistics \& Trends including Average Occupancy, Rates, Global Hotel Industry Trends \& More. https://www.condorferries.co.uk/hotel-industry-statistics. Retrieved October 2, 2021.

6. Seasonality in the tourist accommodation sector. https://ec.europa.eu/eurostat/statisticsexplained/index.php?title=Seasonality_in_the_tourist_accommodation_sector\#By_accommodation_type Retrieved October 2, 2021.

7. Cerović, Z. (2010). Hotelski menadžment. Opatija: Fakultet za hotelski i turistčki menadžment.

8. Bunja, D. (2008). Organizacija poslovanja u hotelijerstvu i turizmu: hotel i hotelijerstvo. Školska knjiga.

9. Nights spent at tourist accommodation establishments. https://ec.europa.eu/eurostat/web/products-datasets//tour_occ_ninatT Retrieved October 2, 2021.

10. Public opinion on how to improve customer comfort levels in hotels after the coronavirus (COVID-19) pandemic worldwide as of May 2020. https://www.statista.com/statistics/1155082/coronavirus-hotels-level-of-comfortimprovement/ Retrieved October 2, 2021.

11. Top 30 mobile marketing stats for hotels. https://www.criton.com/news-hub/30-mobile-marketing-stats-forhotels-in-2019/ Retrieved October 2, 2021.

12. Despite challenges, OTA bookings continue to climb in Europe. https://www.phocuswright.com/TravelResearch/Research-Updates/2019/Despite-challenges-OTA-bookings-continue-to-climb-in-Europe Retrieved October $2,2021$.

13. Dobrianska, N., Nikoliuk, O., \& Lebedieva, V. (2019). Organizational and economic measures of tourism development on the example of the Avangard United Territorial Community of Odessa region. Food Industry Economics, 11(3), Issue 3, 88-96. doi: 10.15673/fie.v11i3.1466

14. Dobrianska, N. A., \& Popovych, V. V. (2018). «Zelenyi» turyzm yak stratehichnyi napriam sotsialnoekonomichnoho rozvytku rehioniv Ukrainy. Ekonomika: Realii Chasu, (3(37), 20-28. Retrieved October 2, 2021, from https://economics.opu.ua/files/archive/2018/No3/20.pdf. doi: 10.5281/zenodo.1326369

15. Houck, J. P. (1984). «Market»: A Definition for Teaching. Western Journal of Agricultural Economics, 353 -356 .

16. Top 10 largest hotel groups of the world. https://www.tourism-review.com/top-10-world-largest-hotelgroups-news1988 Retrieved October 2, 2021.

17. Tahiri, A., Kovaçi, I., \& Lekiqi, B. (2021). Tourism and Hotel Industry: Definition, Concepts and Development - The Case of Kosovo. Quality - Access to Success, (22(182)), 110-115.

Received 17 October 2021

Approved 31 October 2021

Available in Internet 30.12.21

Цитування згідно ДСТУ 8302:2015

Добрянська Н.А., Саркісян Г.О., Ніколюк О.В., Сланська К.В. Аналіз міжнародного ринку готельних послуг: проблеми і тенденції розвитку // Економіка харчової промисловості. 2021. Т.13, вип. 4. С.63-68. doi 10.15673/fie.v13i4.2192

Cite as APA style citation

Dobrianska, N., Sarkisian, G., Nikoliuk, O., \& Yelanska, K. (2021). Analysis of the international market of hotel services: problems and development trends . Food Industry Economics, 13(4), 63-68. doi 10.15673/fie.v13i4.2192 